\title{
Deposit Mobilization and Socio - Economic Impact: A Case Study of Union Bank Of India
}

\author{
Dr. (Smt.) Rajeshwari M. Shettar \\ Associate Professor, Department of Commerce, Shri. Hurakadli Ajja Shikshan Samiti's Smt. K. S. Jigalur Arts \\ and Dr. (Smt.) S. M. Sheshgiri Commerce College for Women, DHARWAD-8.
}

\begin{abstract}
The present study is a modest attempt to analyze the socio-economic impact of bank deposits. Deposit mobilization is an integral part of banking activity. Mobilization of savings through intensive deposit collection has been regarded as the major task of banking in India today. Acceptance of deposits is the primary function of Commercial Banks. As such deposit mobilization is one of the basic innovations in current Indian Banking activity. In this paper, an attempt is made to analyze the socio-economic impact of deposit mobilization. Three different types of deposits namely, term deposits, current deposit and savings deposit is considered for the study. The data required for the study has been collected from Union Bank of India Annual Reports. The data, thus collected have been properly classified and analyzed with the help of simple statistical parameters like Average, Indices etc and also the accounting technique i.e. Ratio Analysis. The results shows that, there has been a remarkable growth in mobilization of all kinds of deposits in Union Bank of India.
\end{abstract}

KEY WORDS: - Deposit Mobilization, Socio - Economic Impact.

\section{INTRODUCTION}

Mobilization of deposits is one of the important functions of banking business. It is an important source of working fund for the bank. Deposit mobilization is an indispensable factor to increase the sources of the banks to serve effectively. Mobilization of deposit plays an important role in providing satisfactory service to different sectors of the economy. The Commercial Banks must tap deposits from urban and rural areas. This helps the banks to provide large amount of funds to priority sectors for development. The success of the banking greatly lies on the deposit mobilization. Performances of the bank depend on deposits, as the deposits are normally considered as a cost effective source of working fund. Mobilization of rural savings is one of the important objectives of the Commercial Banks. It helps to expand banking operations. The RBI encourages the banks to mobilize deposits, by providing subsidy for branch expansion. The successful functioning of commercial banks depends on the extent of funds mobilized. Deposits are the life blood of banking companies. Deposits constitute a vital source of funds required for banking business. There are different types of deposits, with different maturity pattern carrying different rates of interests. Deposit mobilization is depending on the cost of deposits. Mobilization of deposits for a bank is as essential as oxygen for human being. In the post liberalization scenario, the number of players in banking industry has increased considerably which developed competition in bank marketing. 'The survival of the fittest' has made applicable for the banks. To enhance profitability, banks take steps to minimize the expenditure and are forced to mobilize low cost deposits.

In the present context bank's efficiency is measured based on the deposit mix and on the quantum of low cost deposits in the mix. In the present era of competition and with the emergence of private and multinational banks, an ideal mix of deposits is a must to survive. Since the interest paid on deposit forms a big burden on bank, the mobilization of low cost deposits, like current account and savings bank deposit is the urgent need for the bank. Banks borrow and lend, they borrow money by accepting deposits from the public including members of the bank. Deposit mobilization is the chief source of funds to undertake lending operations, for profitable operation, the amount of deposits is very important. The banks should introduce various deposits schemes to attract the public to deposit. It is the size of the deposits that largely decides the lending potential of a bank.

\section{NEED FOR DEPOSITS}

To meet the basic necessities and to improve their per capita income, saving / depositing the money becomes necessary. Deposits help in improving the economy of the people as well the economy of the country. The deposits will curtail the expenditure of the depositor to the extent of deposits.

III. POLICY ON BANK DEPOSIT

The important functions of the bank are to accept deposits from the public for the purpose of lending. Depositors are the major stakeholders of the banking system. With liberalization in the financial system and 
deregulation of interest rates, banks are now free to formulate deposit products within the broad guidelines issued by Reserve Bank of India.

\section{S. Venkateshan (2012) ${ }^{1}$ \\ IV. REVIEW OF LITERATURE}

In the study entitled "An Empirical Approach to Deposit Mobilization of Commercial Banks in Tamil Nadu". The researcher made an attempt to study the trend and growth in deposit mobilization of Scheduled Commercial Banks in Tamil Nadu during the period from 1999-2000 to 2008-2009. The Compound Growth Rate (CGR) and Linear Growth Rate (LGR) were calculated from using simple regression analysis. The study found that, there has been a remarkable growth in mobilization of all kinds of deposits in Scheduled Commercial Banks in Tamil Nadu on the whole.

Pai V.S. (2006) ${ }^{2}$

In the study entitled "Trends in the Indian Banking Industry: Analyses of Inter- regional Trends in Deposits and Credits". The researcher makes an attempt to study the banking industry focuses on broad trends across banks and different regions in India. The study focuses on five groups of banks both private and public sector. Deposit and credit are the two performance criteria. The study revealed that, the performance of banks regarding deposits and credits at the two points of time has been largely similar. The study observed that, private scheduled commercial banks have shown superior performance. The study also reveals that, their growth on these two parameters, at the two points in time, have been comparable between them.

\section{Gagan Bihari Sahu and D. Rajasekhar (2005) ${ }^{3}$}

In the study entitled "Urban Bias in the Flow of Funds and Deposit Mobilization: Evidence from Karnataka, India". The researcher examines the impact of contrasting policies on the flow of credit and deposit mobilization in rural and urban areas in Karnataka State. The study found that, the formal financial institutions tended to gravitate towards urban areas in the credit provision after the reforms were introduced. During the reform period, rural areas witnessed negative net flow of funds through banking channels. The study also found that, one unit increase in deposits leads to less credit flow in rural areas as compared to urban areas.

\section{Dr. Ramchandra Reddy B. and Dr. Yuvaraja Reddy (2005) ${ }^{4}$}

In the study entitled "Financial Performance of State Bank of India: An Analysis". The researchers made an attempt to study the financial performance of State Bank of India. The study focuses on the responsibility areas like deposit mobilization, credit deployment, non-performing assets, profitability and productivity. The study found that, in the changing banking scenario, the State Bank of India is one of the leading banks which welcomes the radical changes and make the organization fit for the changes without much difficulty.

\section{OBJECTIVES OF THE STUDY}

1. To study the Socio - Economic Impact of Deposit Mobilization.

2. To offer useful Suggestions for the Better Management of Deposits.

\section{METHODOLOGY OF THE STUDY}

The study is based on secondary data, collected data from Annual Reports of the Union Bank of India, Reports on Trends and Progress of Banking in India, RBI, Mumbai, Journal of CAB Calling, Pune, Journal of Professional Banker, Periodicals and Books.

VII. PERIOD FOR THE STUDY

This study covers a period of 13 years i.e. from 1999-2000 to 2011-2012.

\section{DEPOSIT MIX}

The bank has offered number of deposit schemes to the public which include term deposits, saving deposits, current deposits and the like. The mobilization of deposits helps the bank to meet the growing demands of various sectors namely, agriculture, small scale industry, weaker section of the community and the like. Current deposits are meant for government, corporate, institutions and business segments where as savings deposits are designed for individuals. Term deposits are targeted predominantly for the household segment and institutions. Though, there was considerable shift in the market share of Government / corporate during the last two decades, the deposit mix remained the same even in the liberalized environment which demonstrates the importance of term deposits. 


\section{TERM DEPOSITS (TD):}

Term deposits are the deposits on which interest is paid, either on maturity or at stipulated intervals depending upon the deposit scheme under which the money is placed. Term deposits include the following:

Fixed deposits: On this a fixed rate of interest is paid at fixed and regular intervals;

* Re-investment deposits: The interest is compounded quarterly and paid on maturity along with the principal amount of the deposit.

* Recurring deposits: Here a fixed amount is deposited at regular intervals for a fixed term and the repayment of principal and interest is made at the end of the term.

\section{SAVINGS BANK DEPOSIT (SBD):}

Savings deposit is the most common type of deposit, which caters to the needs of almost all type of customers. The surplus earned is deposited in the form of savings deposits. This type of deposit is meant for individuals, professional people, small traders, artisans and co-operative societies. Here withdrawals are subject to certain conditions. These deposits are relatively less interest cost oriented. Under this type of deposit interest accrues at a fixed rate set by the RBI (currently 3.5\%) and upon which cheques can be drawn. Savings deposits are the form of demand deposits. Savings deposits are subject to restrictions on the number of withdrawals as well as on the amounts of withdrawals during any specified period. Further, minimum balances may be prescribed in order to offset the cost of maintaining and servicing such deposits. Savings bank accounts are used by a large segment of small depositors as they can put their regular incomes into these accounts. Under this, customer can withdraw the money on demand and also earn interest on the balance left in the account. Savings accounts are generally opened by households.

\section{CURRENT DEPOSITS (CD):}

Current deposit products are designed to cater the banking requirements of businessmen, traders, companies and other entities. This type of deposit is also for the individuals who are involved in commercial or business activities. In addition to conventional current deposit accounts, bank offer variations of the current deposit with value-added services for eligible current account customers. Bank also offers the variety of special value-added products and services. Current deposits cater to the needs of business people who make use of cheque facilities extensively and also receive cheques in their favor from others. This is just to facilitate the business men dealing frequently with the account in the course of business which may necessitate withdrawing their funds at short notice and also frequently depositing their surplus funds. However, there is no restriction that only business people should open current accounts. The bank accepts current deposits from individuals, cooperative societies, government institutions, local bodies etc.

\section{DEPOSIT MOBILIZATION OF UBI}

The volume of deposits and the return on advances are closely related to the deployment of funds. If the deposits are increased, it increases the advances of the bank. For the performance of the banks, growth rate analyses are an important parameter. An increasing trend in growth rate of deposits shows better performance of the Union Bank of India in deposit mobilization. The size of deposits determines the funds available for lending. The growth rate in total deposits of Union Bank of India shows an increasing trend over the period. The higher the growth rates over the period, the higher the level of market orientation of the bank and vice versa. The information relating to the deposit mobilization scenario of Union Bank of India is shown in table 1.1

Table 1.1: TRENDS IN GROWTH RATE OF TOTAL DEPOSITS OF U B I

(Rs. in crore)

\begin{tabular}{|c|r|r|r|}
\hline Year & Total Deposits (Rs. ) & Absolute Growth (Rs. ) & Relative Growth Rate \\
\hline $1999-2000$ & $31,105.36$ & - & - \\
\hline $2000-2001$ & $34,888.06$ & $3,782.70$ & 12.16 \\
\hline $2001-2002$ & $39,793.86$ & $4,905.80$ & 14.06 \\
\hline $2002-2003$ & $44,748.62$ & $4,954.76$ & 12.45 \\
\hline $2003-2004$ & $50,558.93$ & $5,810.31$ & 12.98 \\
\hline $2004-2005$ & $61,830.59$ & $11,271.66$ & 22.29 \\
\hline $2005-2006$ & $74,094.30$ & $12,263.71$ & 19.83 \\
\hline $2006-2007$ & $85,180.22$ & $11,085.92$ & 14.96 \\
\hline $2007-2008$ & $1,03,858.64$ & $18,678.42$ & 21.93 \\
\hline $2008-2009$ & $1,38,702.83$ & $34,844.19$ & 33.55 \\
\hline $2009-2010$ & $1,70,039.74$ & $31,336.91$ & 22.59 \\
\hline $2010-2011$ & $2,02,461.00$ & $32,421.26$ & 19.07 \\
\hline $2011-2012$ & $2,22,869.00$ & $20,408.00$ & 10.08 \\
\hline
\end{tabular}

Source: UBI Annual Reports 
Table 1.1 reflects the deposit mobilization of Union Bank of India over the period of 13 years is $446.66 \%$ growth rate and is in increasing trend from $12.16 \%$ to $22.59 \%$ though it is fluctuating. The total deposit increased from Rs. 31,105.36 crores in 1999-2000 to 1,70,039.74 crore in 2009-10. Thus, there was an absolute growth of $1,38,934.38$ crores over the period. However, the percentage growth rate was not even but marked with regular ups and downs from year to year. Increase in deposits every year reflects the Union Bank of India's effectivness in mobilization of funds for deployment. Union Bank of India is successful in attracting the deposits from the public and thereby it is successful in developing the habit of savings among people. It lead to capital formation and credit creation. As of March, 2010, the total deposits stood at Rs. 170039.74 crore compared to Rs. 138702.83 crore as on $31^{\text {st }}$ March, 2009 resulting in an absolute growth of Rs. 31336.91 crore.

Figure 1.1 DEPOSIT MOBILIZATION OF U B I

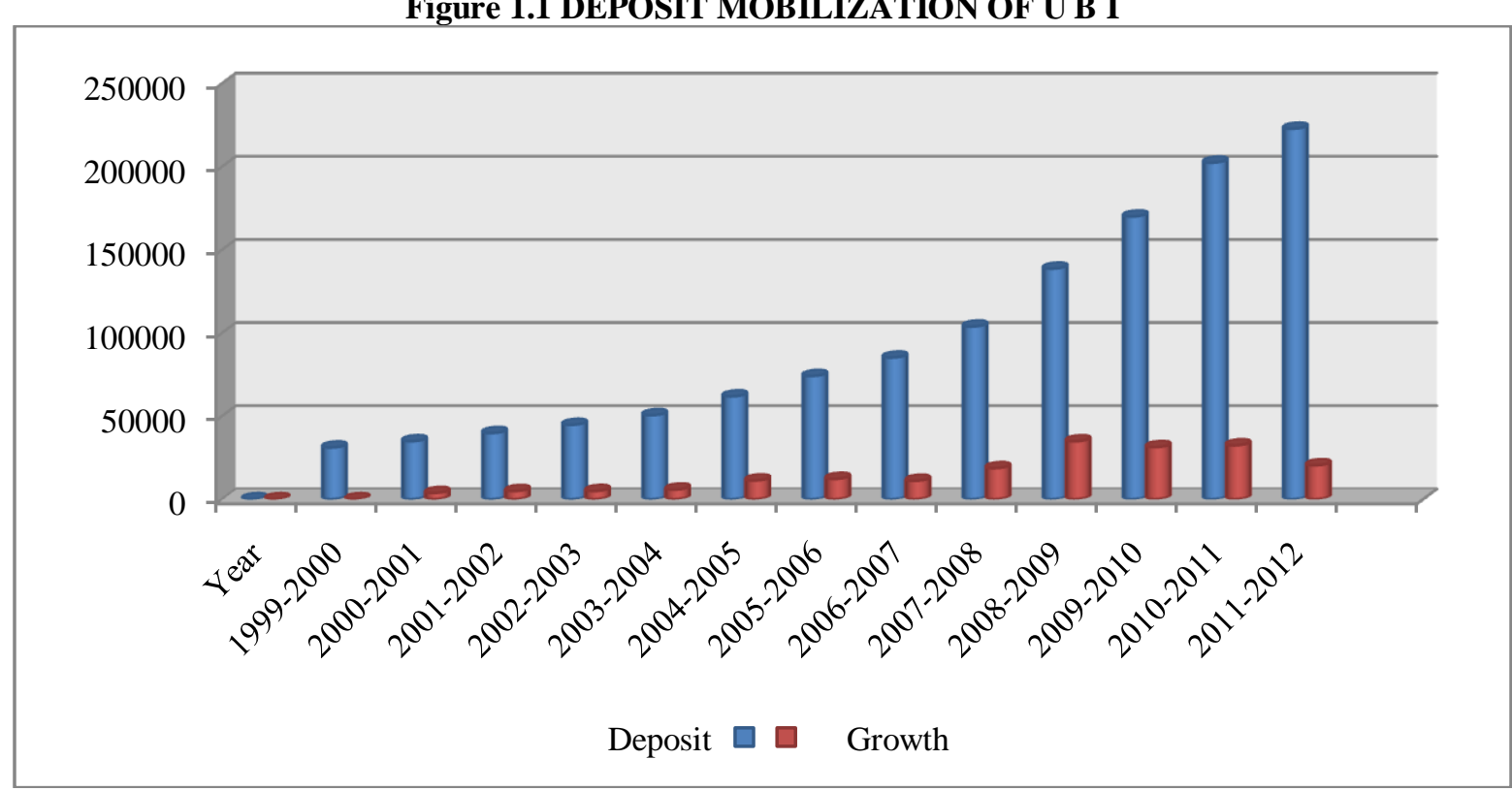

\section{ANALYSIS OF DEPOSIT - MIX OF UNION BANK OF INDIA}

Union Bank of India mobilizes mainly three types of deposits i.e. demand deposits, savings deposits and time (or term) deposits. In order to increase the volume of deposits, the commercial banks are required to tap the different types of investors. If the portfolio of banks deposit is widely diffused, the bank is said to be sensitive to the requirements of the different savers and vice- versa. The information relating to the break up of total deposits mobilized by the bank under study is shown in Table 1.2.

Table 1.2: DEPOSIT-MIX OF UNION BANK OF INDIA

\begin{tabular}{|c|c|c|c|c|}
\hline \multicolumn{1}{|c|}{ Year } & $\begin{array}{c}\text { Current Deposit/Demand } \\
\text { Deposits (CD/DD) }\end{array}$ & $\begin{array}{c}\text { Savings Bank Deposit } \\
\text { (SBD) }\end{array}$ & Term Deposit (TD) & $\begin{array}{c}\text { Total } \\
\text { Deposits }\end{array}$ \\
\hline & 4,829 & 7,430 & 18,846 & 31,105 \\
$1999-2000$ & $(15.52)$ & $(23.89)$ & $(60.59)$ & $(100)$ \\
\hline & 6,496 & 7,592 & 20,800 & 34,888 \\
$2000-2001$ & $(18.62)$ & $(21.76)$ & $(59.62)$ & $(100)$ \\
\hline & 6,654 & 9,701 & 23,438 & 39,793 \\
$2001-2002$ & $(16.72)$ & $(24.38)$ & $(58.90)$ & $(100)$ \\
\hline & 5,036 & 11,171 & 28,541 & 44,748 \\
$2002-2003$ & $(11.25)$ & $(24.96)$ & 32,470 & $(100)$ \\
\hline & 5,004 & $(25.084$ & $41,63)$ & $(100)$ \\
$2003-2004$ & $(9.90)$ & 15,197 & $(67.32)$ & 61,830 \\
& 5,010 & $(24.58)$ & 50,119 & $(100)$ \\
\hline & $(8.10)$ & 17,997 & $(67.64)$ & 74,094 \\
$2004-2005$ & 5,978 & $(24.29)$ & 55,794 & $(100)$ \\
\hline & $(8.07)$ & 20,763 & $(65.50)$ & 85,180 \\
$2006-2007$ & 8,623 & $(24.38)$ & & $(100)$ \\
\hline
\end{tabular}


Deposit Mobilization and Socio - Economic Impact: A Case Study of Union Bank of India

\begin{tabular}{|c|c|c|c|c|}
\hline & 11,836 & 24,368 & 67,654 & $1,03,858$ \\
$2007-2008$ & $(11.40)$ & $(23.46)$ & $95.14)$ & $(100)$ \\
\hline & 13,166 & 28,545 & $(69.93)$ & $1,38,703$ \\
$2008-2009$ & $(9.49)$ & $(20.58)$ & $1,16,083$ & $(100)$ \\
\hline & 16,229 & 37,728 & $(68.27)$ & $(100)$ \\
\hline & $(9.54)$ & $(22.19)$ & $1,38,154$ & $2,02,461$ \\
$2009-2010$ & 19,618 & 44,689 & $(68.24)$ & $(100)$ \\
\hline & $(9.69)$ & $(22.07)$ & $1,53,164$ & $2,22,869$ \\
$2010-2011$ & 12,595 & 57,110 & $(68.73)$ & $(100)$ \\
\hline
\end{tabular}

Source: UBI Annual Reports

Note: Figures within the parentheses denotes the percentages of the respective figure to the respective row totals.

Table 1.2 indicates that, the bank under study like any other commercial banks has been able to mobilize only three types of deposits i.e. current deposit, savings deposit, and term deposits. Therefore, it may be said that the deposit mix of Union Bank of India is conventional in nature. It also indicates that the term deposits share is comparatively high out of the total deposit. Growth of the term deposit is also in an increasing trend over the period. This shows that Union Bank of India has been term deposit centered rather than current and savings deposit. The share of current deposits has been relatively less indicating that the Union Bank of India has not been able to attract more and more deposits from the business units. Growth over the study period is fluctuating. From 2000 to 2006 negative growth percentage and from 2006 to 2009 positive growth percentage in case of deposit mix.

Figure 1.2: DEPOSIT MIX OF UNION BANK OF INDIA

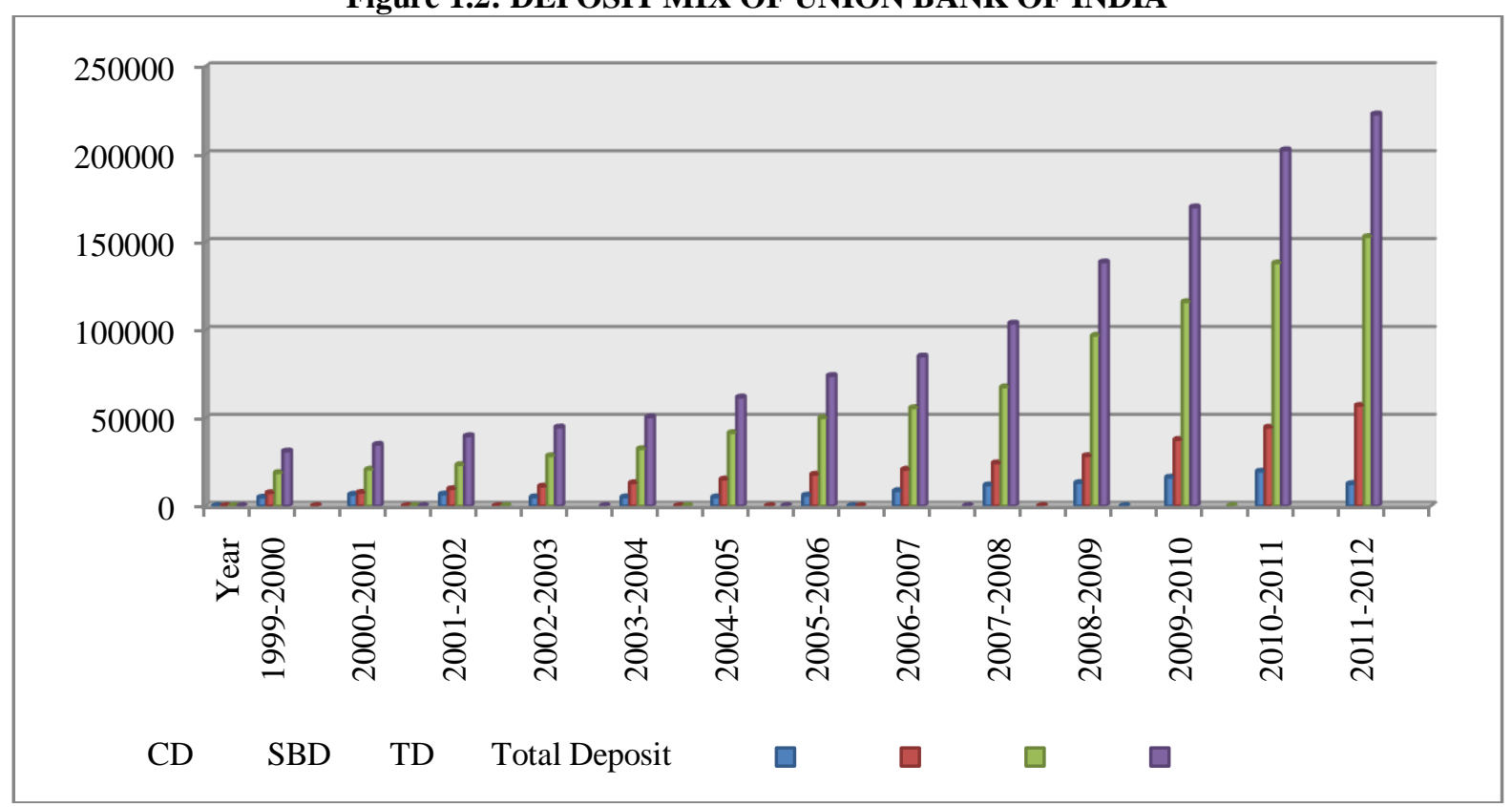

\section{XI. $\quad$ SOCIO - ECONOMIC IMPACT OF DEPOSIT MOBILIZATION}

These different kinds of deposits have direct social and economic impact on the society. This clearly shows that the Union Bank of India played a vital role in uplifting the social and economic position of the Nation by deposit mobilization. Towards resources mobilization, Union Bank of India focused on current and savings account and a retail term deposits. The bank registered a growth of $446.66 \%$ growth rate in total deposits during the yer under review. As of March, 2010, the total deposits stood at Rs. 1,70,039.74 crore, compared to Rs. 31,105.36 crores in March, 2000 resulting in an absolute increase of 1,38,934.38 crores. Union Bank has a team of customer relationship managers, resource marketing officers and relationship offficers focused on building and nurturing customer relationships. As a result, bank added 33 lakh new savings bank accounts and 86,000 new current accounts mobilizaed during the year. The household sector continued to show preferance for bank deposits, due to the traditional considerations of safety, security and liquidity. Bank kept itself abreast of the market opportunities and continued to focus on retail deposits and tapping of long-term household savings. Union Bank launched specific term deposit scheme like 555 days. Thus, consistant and 
focused strategy on current and savings account and retail deposits resulted in yielding excellent growt, in a cost effective manner. The banking sector will be the key facilitator and beneficiary of India's growth. Union Bank of India is geared to continue with the grow momentum, well supported by the efficient resource mobilization and its gainful development. The Nav Nirman initiatives are expected to further enhance the customers experience through best in class products and services offering value for money, commited turn- around time, accessibility and transparency.

\section{FINDINGS OF THE STUDY}

[1] Increase in deposits every year reflects the Union Bank of India's effectivness in mobilization of funds for deployment.

[2] Union Bank of India is successful in attracting the deposits from the public and thereby it is successful in developing the habit of savings among people.

[3] The deposit mix of Union Bank of India is conventional in nature, it indicates that the term deposits share is comparatively high out of the total deposit.

[4] Growth of the term deposit is also in an increasing trend over the period. This shows that Union Bank of India has been term deposit centered rather than current and savings deposit.

\section{SUGGESTIONS}

[1] The banks should introduce various deposits schemes to attract the public.

[2] To meet the basic necessities and to improve the per capita income, saving / depositing the money becomes necessary.

[3] In the ever increasing competition amongst banks to increase market shares and retain customer loyalty, the need to provide banking services in a flawless manner and at a low cost is acutely felt, more so in the recent times.

[4] The banks should create awareness of the existence and availability of support services among the customers.

\section{CONCLUSION}

For over Nine decades the Union Bank of India have earned the reputation of being techno-savvy bank and is one of the front runners amongst public sector bank in the field of technology. With its prudent management and good governance, banks non-performing assets were comparatively lower. Bank is firmly committed to consolidating and maintaining its identity as a leading, innovative Commercial Bank, with a proactive approach to the changing needs of the society. This is because of number of products and services made available to its valuable customers. Today, with its efficient, value-added services, sustained growth, consistent profitability and development of new technologies, Union Bank of India has ensured complete customer delight, living up to its image of, "GOOD PEOPLE TO BANK WITH". The key to the success of any organization lies with its people. The Bank, as a good corporate citizen, has stepped into the arena of counseling the common man to help them and lead a decent and honorable life in the future days to come. Though they have made good progress in technology, the challenge lies in quickly disseminating these products amongst their clientele and also present themselves as a techno-savvy bank, particularly to the younger generation of the society.

\section{REFERENCES}

[1] S. Venkateshan "An Empirical Approach to Deposit Mobilization of Commercial Banks in Tamil Nadu", IOSR Journal of Business and Management (IOSR-JBM) Vol. 4, Issue 2 September - October, 2012.

[2] V. S. Pai "Trends in the Indian Banking Industry: Analyses of Inter-Regional Trends in Deposits and Credits", The Icfaian Journal of Management Research January, 2006.

[3] Gagan Bihari Sahu and D. Rajasekhar "Urban Bias in the Flow of Funds and Deposit Mobilization: Evidence from Karnataka, India”, Working paper No. 3 Centre for Social Studies, Veer Narmad South Gujarat University Campus Udhna - Magdalla, SURAT, Gujrat State, September, 2005.

[4] Dr. B. Ramchandra Reddy and Dr. Yuvaraja Reddy "Financial Performance of SBI: An Analysis", Journal of Banking Finance May, 2005.

[5] Avneet Kaur "An empirical study on the performance evaluation of public sector Banks in India", International Journal of Marketing, Financial Services and Management Research Vol. 1 Issue 11, November, 2012.

[6] Dr. M. Syed Ibrahim "Operational performance of Indian Scheduled Commercial Banks - An Analysis", International Journal of Business and Management, Vol. 6, No. 5, May, 2011.

[7] Jaynal Ud -Din Ahmed "Growth of Bank Deposits and Its Determinants: A Pragmatic Study on Commercial Banks", The IUP Journal of Financial Economics, Vol. VII, issue 1, 2009.

[8] Websites: (a) www.unionbankofindia.com

(b) www.rbi.org.in 